Vol.45, n. 4 : pp. 473-477, December 2002 ISSN 1516-8913 Printed in Brazil

\title{
Bionomic Aspects of Pattonella intermutans (Thomson, 1869) (Diptera, Sarcophagidae) under laboratory conditions
}

\author{
Vanderleia Cristina de Oliveira ${ }^{1 *}$, Rubens Pinto Mello ${ }^{2}$ and Rosicleide Fátima Silva Santos ${ }^{1}$ \\ ${ }^{I}$ Laboratório de Biologia e Controle de Insetos Vetores; Departamento de Biologia; Instituto Oswaldo Cruz; \\ Av. Brasil 4365; 21045-900; vcris@ioc.fiocruz.br; Rio de Janeiro - RJ - Brazil. ${ }^{2}$ Laboratório de Diptera; \\ Departamento de Entomologia; Instituto Oswaldo Cruz; Av. Brasil 4365; 21045-900; Rio de Janeiro - RJ - Brazil
}

\begin{abstract}
Life and fertility tables of Pattonella intermutans (Thomson, 1869) were studied in the laboratory conditions. The flies colonies were maintained at $20-28^{\circ} \mathrm{C}, 80 \pm 10 \% \mathrm{RH}$ and observed daily. Life expectancy was 2.34 weeks for males and 2.33 weeks for females. The survivorship curves presented a type II tendency for females and type III for males. The periods of pre-larviposition and larviposition were of 2.5 and 9.5 weeks, respectively. Using data of the life table of fertility, the following values were obtained: Ro=24.83 times; $T=5.06$ weeks; $r=0.64$ and $\lambda=1.89$. The number of generations of $P$. intermutans was estimated to be 10.28 generations/year. The females had a high fertility under laboratory contiditions.
\end{abstract}

Key words: Diptera, Sarcophagidae, Pattonella intermutans, bionomic, ecology

\section{INTRODUCTION}

Pattonella intermutans (Thomson, 1869) (Diptera, Sarcophagidae) is found throughout the Americas with a wide distribution in Central and South America. In Brazil, Lopes (1969) observed this species in the states of Pará, Goiás, Mato Grosso, Rio de Janeiro and São Paulo. Linhares (1979) observed it in Campinas, d'Almeida (1983) in Rio de Janeiro and Dias (1983) in Belo Horizonte and classified it as a hemisynantropic species. There are very few studies about the biology of the species.

Taxonomics and morfologics studies were reported by Lopes (1973) and Jiron and Bolaños (1986). Salviano (1996) emphatized the importance of this muscoid for the forensic entomology. The objective of the present study was to elucidate some aspects of the $P$. intermutans under laboratory conditions.

\section{MATERIALS AND METHODS}

Colonies of $P$. intermutans were established at the Laboratory of Biology and Control of Vector Insects in the Biology Department of the Instituto Oswaldo Cruz. These colonies were compound of third instar larvae and adults collected in traps as described by Ferreira (1978). The traps were baited with dead mice and exposed for 24 hours at the campus of Institute. Ninety couples of $P$ intermutans from the second laboratory generation were used. Immediately after the emergence, the adults were sexed and then transferred to three wood cages of $30 \times 30 \times 30 \mathrm{~cm}$ with contained 30

\footnotetext{
*Author for correspondence
} 
couples in each cage. The flies were daily fed with raw sugar, water ad libitum and minced bovine meat which, served both as a protein supplement for ovarian development and as larviposition medium. The larviposition substrate was kept during $24 \mathrm{~h}$ in the cages and changed daily. The experiments were done under the environmental conditions. Temperature ranged on average from a maximum of $28^{\circ} \mathrm{C}$ and minimum $20^{\circ} \mathrm{C}$. Relative humidity was $80 \pm 10 \%$. The number of dead adults and larvae found on the meat was registered daily in order to evaluate the pre-larviposition and larviposition periods, fertility table, life tables, survivorship curves and the mean males and females longevity.

A life expectancy and fertility tables were constructed based on Andrewarth and Birch (1954), Southwood (1966) and Silveira Neto et al. (1976). The parameters were organized into columns in function of the age interval (x) measured in weeks. The survivor's number from the first group in each of the $\mathrm{x}$ interval was represented by $\mathrm{Lx}$ the fraction of dead insects between the $\mathrm{x}$ and $\mathrm{x}+1$ ages $(\mathrm{dx})$ was estimated by $L_{x}-L_{x+1}$. The Ex value represents the age structure, calculated by $\mathrm{L} x+\mathrm{L} x+1 / 2$. The Tx value is the sum of $E_{x}+E_{x+1}+E_{x+2}+\ldots+E_{w}$, where $\mathrm{w}$ is the maximum age in weeks. The life expectancy (ex), was estimated by $\mathrm{T}_{\mathrm{x}} / \mathrm{L}_{\mathrm{x}}$. The mortality ratio (qx) by age interval was estimated by $1000 d_{x} / L_{x}$.
On the fertility table the parameters were also arranged in columns. The total number of larvae per female per week was represented by $\mathrm{mx}$ and the probability of survivorship on the mean point of the age interval was represented by $1 x$. In this study the sex ratio was maintained 1:1. In order to facilitate the calculus and understanding of these parameters three extra columns were added: total number of larvae (TNL), number of alive females at $x$ age interval (F) and mean number of larvae per female (MNL). Using this data the followings parameters were calculated: liquid reproductive rate (Ro), intrinsic rate of natural increase (r), generation time $(\mathrm{T})$ and finite rate of increase $(\lambda)$, by: $\mathrm{Ro}=\sum$ lx.mx; r= $\log$ Ro $/ \mathrm{T}$. $\log$ e; $\mathrm{T}=\sum$ 1x.mx.x $/ \sum 1 \mathrm{x} . \mathrm{mx} ; \lambda=\operatorname{anti} \log (\mathrm{r} . \log \mathrm{e})$

\section{RESULTS AND DISCUSSION}

Table 1 shows the life expectancy of males and females of $P$. intermutans in laboratory conditions. The values of Lx, Ex and Tx of $P$. intermutans at the beginning of age $\mathrm{x}$, showed gradient of values for both sexes. Comparing the qx values between males and females, it could be observed that the male's mortality by age interval until the $7^{\text {th }}$ week was higher than the female's one. From the $8^{\text {th }}$ week this pattern changed to the opposite way.

Table 1 - Life table of males and females of Pattonella intermutans under laboratory conditions $\left(20-28^{\circ} \mathrm{C}, 80 \pm 10 \%\right.$ $\mathrm{RH})$.

\begin{tabular}{|c|c|c|c|c|c|c|c|c|c|c|c|c|}
\hline \multirow{2}{*}{$\begin{array}{c}\text { X } \\
\text { Weeks }\end{array}$} & \multicolumn{6}{|c|}{ Males } & \multicolumn{6}{|c|}{ Females } \\
\hline & $\mathrm{Lx}$ & $\mathrm{dX}$ & Ex & $\mathrm{Tx}$ & ex & $1000 \mathrm{qx}$ & Lx & $\mathrm{dX}$ & Ex & $\mathrm{Tx}$ & ex & $1000 \mathrm{qx}$ \\
\hline 1 & 1000 & 125 & 937.5 & 4616.0 & 4.61 & 125,0 & 1000 & 63 & 968.5 & 5714.0 & 5.71 & 63.0 \\
\hline 2 & 875 & 29 & 860.5 & 3678.5 & 4.20 & 33.1 & 937 & 23 & 925.5 & 4745.5 & 5.06 & 24.5 \\
\hline 3 & 846 & 119 & 786.5 & 2818.0 & 3.33 & 140.6 & 914 & 68 & 880.0 & 3820.0 & 4.17 & 74.3 \\
\hline 4 & 727 & 141 & 656.5 & 2031.5 & 2.79 & 193.9 & 846 & 102 & 795.0 & 2940.0 & 3.47 & 120.5 \\
\hline 5 & 586 & 158 & 507.0 & 1375.0 & 2.34 & 269.6 & 744 & 119 & 684.5 & 2145.0 & 2.88 & 159.9 \\
\hline 6 & 428 & 136 & 360.0 & 868.0 & 2.02 & 317.7 & 625 & 158 & 546.0 & 1460.5 & 2.33 & 252.8 \\
\hline 7 & 292 & 130 & 227.0 & 508.0 & 1.73 & 445.2 & 467 & 141 & 396.5 & 914.5 & 1.95 & 301.9 \\
\hline 8 & 162 & 45 & 139.5 & 281.0 & 1.73 & 277.7 & 326 & 119 & 266.5 & 518.0 & 1.58 & 365.0 \\
\hline 9 & 117 & 42 & 96.0 & 141.5 & 1.2 & 358.9 & 207 & 107 & 153.5 & 251.5 & 1.21 & 516.9 \\
\hline 10 & 75 & 67 & 41.5 & 45.5 & 0.6 & 893.3 & 100 & 62 & 69.0 & 98.0 & 0.98 & 620.0 \\
\hline 11 & 8 & 8 & 4.0 & 4.0 & 0.5 & 1000.0 & 38 & 28 & 24.0 & 29.0 & 0.76 & 736.8 \\
\hline 12 & & & & & & & 10 & 10 & 5.0 & 5.0 & 0.5 & 1000.0 \\
\hline
\end{tabular}

$\mathrm{x}$ : age in weeks; Lx: number of individuals alive between age $\mathrm{x}$ and $\mathrm{x}+1$; dx: number of dying between age $\mathrm{x}$ and $\mathrm{x}+1$; Ex: number of living individuals between age $\mathrm{x}$ and $\mathrm{x}+1$; Tx: number of individuals alive beyond of age $\mathrm{x}$; ex- life expectancy per individual at the age $\mathrm{x} ; 1000 \mathrm{qx}$ : rate of death (number dying between $\mathrm{x}$ and $\mathrm{x}+1$ among 1000 of age $\mathrm{x}$ ). 
The survivorship of females of $P$. intermutans was higher than that of the males (Figure 1). Based on this characteristic the females survivorship curve tended to type II, while the males one tended to type III, where $\mathrm{dx}$ decreased gradually by each $\mathrm{x}$ interval.

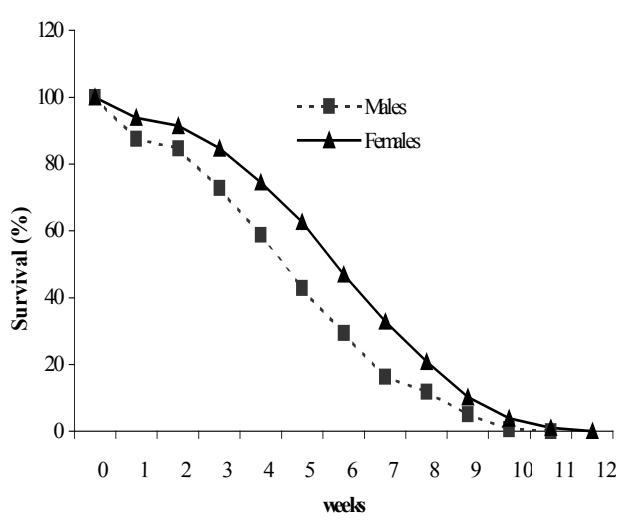

Figure 1 - Survivorship curve of males and females the Pattonella intermutans under laboratory conditions (20$\left.28^{\circ} \mathrm{C}, 80 \pm 10 \% \mathrm{RH}\right)$.

The life expectancy (ex) of 50\% for P. intermutans was 2.34 weeks for males and 2.33 for females. These values demonstrated that the females had the longevity near to the male's one. This fact could be explained by the big energy expenditure in both sexes, in the females due to ovarian development and in males due to sexual expenditure in the mate that took a lot of time and required high sexual activity in the early stages. These results were not in accordance to Mackerras (1933) who studied different fly species and reported that females lived more than males. Ferraz (1992) also observed higher lifetime for the females of the sarcophagyds, Peckia chrysostoma (Wiedemann, 1830) and Adiscochaeta ingens (Walker, 1849). On the other hand, Salviano et al. (1996) found higher lifetime for males of Squamatoides trivittatus (Curran, 1927) (Sarcophagidae). The flies kept at $27^{\circ} \mathrm{C}$ temperature showed reduced longevity than on a $16^{\circ} \mathrm{C}$ temperature probably because higher temperatures accelerated the metabolism decreasing the longevity.

Females of $P$. intermutans began the larviposition on the 3.5 week after emerging. Figure 2 showed that the larviposition period was 9.5 weeks with successive peak and decrease in the larvae deposition number. Similar result was observed by Ferraz (1992) in P. chrysostoma and A. ingens, with long period of pre-larviposition of 21.4 days and 15..3 days and period of larviposition of 35.2 and $21 . .5$ days, respectively.

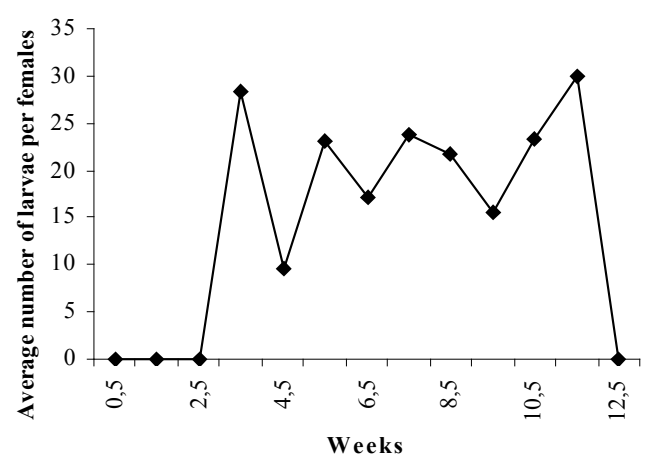

Figure 2 - Average number of larvae per female as a function of age in Pattonella intermutans under laboratory conditions $\left(20-28^{\circ} \mathrm{C}, 80 \pm 10 \% \mathrm{RH}\right)$.

However, the major part of the Calliphoridae species have a relatively short gonadotrophic cycle (Avancini and Prado, 1986 and Ferro and d'Almeida, 1998), what was not observed for the species of the present study. There is necessity for studies on the ovarian development of Sarcophagidae species, because it differs the ovoviparous species by the chorions of the eggs break during the larviposition and the females lay directly the first stage larvae, istead of eggs.

Table 2 shows a better evaluation of the development of $P$. intermutans. Using the data in this table it was estimated how many times the population increased per generation $(\mathrm{Ro}=24.83$ times), the mean generation time $(\mathrm{T}=5.06$ weeks $)$ and the intrinsic rate of population increase $(\mathrm{r}=$ $0.64)$. The number of female individuals added to the population by female per week $(\lambda)$ was 1.89 , so that the number of females added to the population in one generation $\left(\lambda^{\mathrm{T}}\right)$, was 24.83 females. Under the laboratory conditions, the expected number of $P$. intermutans generation was of approximately 10.28 generations per year.

The survivorship and fertility of the adult flies in laboratory depended on feeding, temperature, cage size and sex ratio (Ferraz, 1992). In this study, some of these conditions were optimized. Certainly in nature the environmental resistance is 
higher, caused by oscillating abiotic factors, predators, access to nutritional sources, as well as intra and inter-specific competition. Studies of this species biology were not made yet and the parameters found in this study under the established conditions could serve as subsides and models for studies of the dipterous muscoids biology and ecology.

$\underline{\text { Table } 2 \text { - Fertility life table of Pattonella intermutans, under laboratory conditions }\left(20-28^{\circ} \mathrm{C}, 80 \pm 10 \% \mathrm{RH}\right)}$.

\begin{tabular}{cccccccc}
\hline X & & & & & & & \\
Weeks & $\mathrm{mx}$ & $\mathrm{NTL}$ & $\mathrm{F}$ & $\mathrm{NML}$ & $\mathrm{lx}$ & $\mathrm{mx} .1 \mathrm{x}$ & mx.lx.x \\
\hline 0,5 & 0 & 0 & 0 & 0 & 0,93 & 0 & 0 \\
1,5 & 0 & 0 & 166 & 0 & 0,91 & 0 & 0 \\
2,5 & 0 & 0 & 162 & 0 & 0,84 & 0 & 0 \\
3,5 & 14,1 & 4.244 & 150 & 28,29 & 0,74 & 10,43 & 36,51 \\
4,5 & 4,1 & 1.273 & 132 & 9,64 & 0,62 & 2,54 & 11,43 \\
5,5 & 11,5 & 2.563 & 111 & 23,09 & 0,46 & 5,29 & 29,09 \\
6,5 & 8,5 & 1.415 & 83 & 17,05 & 0,32 & 2,72 & 17,68 \\
7,5 & 11,8 & 1.379 & 58 & 23,78 & 0,20 & 2,36 & 17,70 \\
8,5 & 10,8 & 802 & 37 & 21,68 & 0,10 & 1,08 & 9,18 \\
9,5 & 7,7 & 279 & 18 & 15,50 & 0,04 & 0,30 & 2,18 \\
10,5 & 11,7 & 164 & 7 & 23,43 & 0,01 & 0,11 & 13,44 \\
11,5 & 15,0 & 60 & 2 & 30,00 & 0,00 & 0,00 & 0 \\
$\boldsymbol{\Sigma}$ & & & & & & $\mathbf{2 4 , 8 3}$ & $\mathbf{1 2 5 , 5 9}$ \\
\hline
\end{tabular}

x: age in weeks; NTL: total number of deposited larvae at the age $\mathrm{x}$; F: living females at the age $\mathrm{x}$; NML: average number of larvae per female; mx: average number of larvae laid by a female aged $\mathrm{x}$; lx: percent survivors to age $\mathrm{x}$.

\section{RESUMO}

Tabelas de vida e de fertilidade de Pattonella intermutans (Thomson, 1869) foram estudadas em condições de laboratório. As colônias foram observadas diariamente e mantidas a $20-28^{\circ} \mathrm{C}$ e $80 \pm 10 \%$ RH. A expectativa de vida foi de 2,34 semanas para machos e de 2,33 semanas para as fêmeas. As curvas de sobrevivência tenderam para o tipo II, nas fêmeas e do tipo III, nos machos. Os períodos de pré-larviposição e larviposição foram de 2,5 e de 9,5 semanas, respectivamente. Utilizando os dados da tabela de fertilidade, foram obtidos os seguintes valores: $\mathrm{Ro}=24,83 ; \mathrm{T}=5.06$ semanas; $\mathrm{r}=0,64$ e $\lambda=1,89$. O número de gerações de $P$. intermutans foi estimado em 10,28 gerações por ano. Nas condições de laboratório empregadas, as fêmeas tiveram alta fertilidade.

\section{REFERENCES}

Andrewartha, H. G. and Birch, L. C. (1954), The distribution and abundance of animals. University of Chicago Press, Chicago.

Avancini, R. M. P. and Prado, A. P. (1986), Oogenesis in Chrysomya putoria (Wiedemann) (Diptera: Calliphoridae). Int. J. Insect. Morphol. and Embriol., 15, 375-384.
d'Almeida, J. M. (1984), Sinantropia de Sarcophagidae (Diptera) ma região metropolitana do Estado do Rio de Janeiro. Arq. Univ. Fed. Rur. RJ, 7, 101-110.

Dias, E. S.; Neves, D. P. and Lopes, H. S. (1984), Estudos sobre a fauna de Sarcophagidae (Diptera) em Belo Horizonte, MG: I - Levantamento taxonômico e sinantrópico. Mem. Inst. Oswaldo Cruz., 79, 83-91.

Ferraz, M. V. (1992), Comparision of the reproductive behavior between isolated Peckia Chrysostoma (Wiedemann, 1830) and Adiscochoeta ingens (Walker, 1849) (Diptera: Sarcophagidae) females reared in laboratory. Mem. Inst. Oswaldo Cruz, 87, 131-139.

Ferreira, M. J. M. (1978), Sinantropia de dípteros muscóides de Curitiba, Paraná. I. Calliphoridae. Rev. Bras. Biol., 38, 445-454.

Ferro, L. M. and d'Almeida, J. M. (1998), Influência de diferentes dietas no desenvolvimento ovariano de Chrysomya megacephala. Entomologia y Vectores., 5, 179-189.

Jirón, L. F. and Bolaños, R. (1986), Biology and larval morphology by scanning electron microscopy of Pattonella intermutans Walker (Diptera Sarcophagidae). Rev. Bras. Ent., 3027-30.

Linhares, A. X. (1981), Sinantropy of Calliphoridae and Sarcophagidae in the city of Campinas, SP, Brazil. Rev. Bras. Ent., 25189-215.

Mackerras, M. J. (1933), Observations on the lifehistories, nutritional requirements and fecundity of blow flies. Bull. Entomol. Res., 24353-362. 
Lopes, H. S. (1969), Family Sarcophagidae. In: $A$ Catalogue of the Diptera of the Americas South of the United States. Museu de Zoologia da Universidade de São Paulo, Brasil. pp. 88.

Lopes, H. S. (1973), Collecting and rearing Sarcophagidae flies (Diptera) in Brazil during forty years. An. Acad. Bras. Ci., 45279-291.

Salviano, J. B. (1996), Sucessão de Diptera Caliptrata em carcaça de Sus scrofa Linnaeus, Rio de Janeiro, RJ. Tese Mestrado. Universidade Federal Rural do Rio de Janeiro, Brasil.

Salviano, J. B.; Mello, R. P.; Beck, L. C. N. H. and d'Almeida, J. M. (1996), Aspectos Bionômicos de Squamatoides trivittatus (Diptera, Sarcophagidae) sob condições de Laboratório. Mem. Inst. Oswaldo Cruz, 91, 249-253.

Silveira Neto, S.; Nakano, O.; Barbin, D. and Villa Nova, N. A. (1976), Manual de Ecologia de Insetos. São Paulo : Ed. Agronômica Ceres.

Southwood, T. R. E. (1966), Ecological methods. London : Chapman and Hall.

Received: September 18, 2000;

Revised: March 06, 2001;

Accepted: January 18, 2002. 